DOI 10.14746/ssp.2018.2.3

Krzysztof ŻARNA

Uniwersytet Rzeszowski

\title{
Przed rozwodem. Sytuacja polityczna na Słowacji w ramach Czeskiej i Słowackiej Republiki Federacyjnej (1990-1992)
}

Streszczenie: Po ,aksamitnej rewolucji” w Czechach i na Słowacji w 1990 r. odbyły się wybory do Zgromadzenia Federalnego. Zwyciężyły w nich dwa ruchy polityczne: Forum Obywatelskie i Społeczeństwo Przeciwko Przemocy. W przypadku wyborów do Słowackiej Rady Narodowej większość partii politycznych akcentowała chęć akcesji do struktur europejskich oraz równouprawnienia $\mathrm{w}$ ramach federacji. Z czasem narastały rozbieżności pomiędzy Czechami a Słowakami odnośnie wizji przyszłego państwa. Spośród polityków czeskich i słowackich odrębność akcentowali Vacláv Klaus i Vladimír Mečiar oraz przedstawiciele partii nacjonalistycznych. Z kolei największym orędownikiem utrzymania federacji był prezydent Vacláv Havel. W związku z narastającymi tendencjami nacjonalistycznymi wśród Czechów i Słowaków proces dezintegracji wspólnego państwa był nie do powstrzymania. Ostatecznie 1 stycznia 1993 r. na politycznej mapie Europy pojawiły się dwa nowe państwa: Republika Czeska i Republika Słowacka.

Słowa kluczowe: Czeska i Słowacka Republika Federacyjna, Vacláv Klaus, Vladimír Mečiar, Vacláv Havel, rozpad

Viniejszy artykuł dotyczy analizy sytuacji politycznej na Słowacji W ramach Czeskiej i Słowackiej Republiki Federacyjnej (Česka a Slovenská Federativní Republika, ČSFR). Autor starał się odpowiedzieć na pytania: jak kształtowała się polityka wewnętrzna na Słowacji w okresie istnienia wspólnego państwa z Czechami? W jaki sposób doszło do dezintegracji Czeskiej i Słowackiej Republiki Federacyjnej? Czy była jakakolwiek szansa na uratowanie federacji? Artykuł opiera się na założeniu, że w latach 1990-1992 tendencje dezintegracyjne były na tyle silne, że nie udało się powstrzymać procesu rozpadu Czechosłowacji. W niniejszym opracowaniu wykorzystano metodę analizy systemowej w celu ukazania systemu partyjnego na Słowacji. Wykorzystano również analizę decyzyjną polegającą na przedstawieniu sytuacji i pro- 
cesów, które doprowadziły do rozpadu wspólnego państwa Czechów i Słowaków.

Rok 1989 zapoczątkował szereg przemian w Europie Środkowej, które przeszły do historii jako ,jesień narodów” i nie ominęły również Czechosłowacji (Rychlík, 1999, s. 76-79; Suk, 1997; Szczepaniak, 1995, s. 53). Znaczącym krokiem w kierunku demokratycznego państwa było uchwalenie Karty Praw i Swobód Obywatelskich, która zawierała cały katalog praw człowieka zgodny ze standardami międzynarodowymi. Zaczęto wprowadzać pluralizm w nauce i kulturze. Rozpoczął się proces rozliczania z poprzednim systemem poprzez wprowadzenie lustracji deputowanych do parlamentu federalnego, członków i pracowników rządu federalnego oraz pracowników naczelnych organów administracji publicznej. Wiele kontrowersji wzbudziło wprowadzenie ustawy zakazującej współpracownikom byłej służby bezpieczeństwa i niektórym działaczom partii komunistycznej podejmowania pracy na określonych stanowiskach publicznych przez okres pięciu lat (Orlof, 2003, s. 254).

Przyjmując za punkt wyjścia ewolucję systemu politycznego na Słowacji, Radosław Zenderowski podzielił okres tranzycji na sześć etapów: - od implozji reżimu totalitarnego do tzw. wyborów podstawowych (1989-1990);

- okres wprowadzenia instytucjonalnych podstaw demokracji (19901992);

- okres dyskontynuacji rozwoju prawno-państwowego i transformacyjnego (1992-1994);

- okres reżimu demokracji delegowanej (1994-1998);

- okres starań o konsolidację demokracji (1998-2002);

- okres demokracji skonsolidowanej: po 2002 r. (Zenderowski, 2007, s. 298-299; por. Kopeček, 2003, s. 158-166).

Obok transformacji politycznej, gospodarczej i społecznej, rozpoczął się też proces dezintegracji wspólnego dotąd państwa Czechów i Słowaków. Zgromadzenie Federalne oraz rady obu republik zadecydowały o zreformowaniu systemu politycznego. Pod naciskiem słowackich ugrupowań politycznych, w kwietniu 1990 r. uchwałą parlamentu zmieniono nazwę państwa na Czeską i Słowacką Republikę Federacyjną (Ústavný). W wyniku nacisku radykalnych polityków słowackich w dniu 20 kwietnia parlament poprawił oficjalną nazwę państwa na Czeska i Słowacka Republika Federacyjna. Było to wydarzenie określane jako „wojna o myślnik". W ocenie uczestnika tamtych wydarzeń, późniejszego prezydenta Republiki Słowackiej Rudolfa Schustera, dla Słowaków było to za mało. 
Pragnęli oni podkreślenia własnej samodzielności chociażby w sferze symboli: odrębnej konstytucji, flagi, godła, hymnu. Mówiło się o „czeskich Tatrach” i „,czeskiej koronie” zapominając, że istnieją też Słowacy (Schuster, 1999, s. 36).

Na początku 1990 r. rozgorzała dyskusja wokół rozwiązań proceduralnych w nowej ordynacji wyborczej. Ostatecznie została ona uchwalona 27 lutego. Określała zasady odbywania wyborów do Izby Ludu i Izby Narodów Zgromadzenia Federalnego. Zostały również ustalone przez parlamenty republikańskie: ustawa wyborcza do Czeskiej Rady Narodowej i Słowackiej Rady Narodowej. W dniach 8-9 czerwca 1990 r. odbyły się w Czechosłowacji wybory parlamentarne do obu izb Zgromadzenia Federalnego i parlamentów republikańskich. W wyborach do Izby Ludu (Czesi i Słowacy byli reprezentowani proporcjonalnie do liczby ludności) i Izby Narodów (Republika Czeska i Republika Słowacka były reprezentowane po 75 przedstawicieli) w parlamencie znaleźli się przedstawiciele dziewięciu partii politycznych. Zwyciężyły dwa ruchy polityczne związane z ,aksamitną rewolucją": Forum Obywatelskie (Občanske forum, OF) i Społeczeństwo Przeciwko Przemocy (Verejnost' proti nasiliu, VPN). W Izbie Ludu OF uzyskało ok. 50\% głosów, a VPN 37,3\%. Drugą siłą polityczną w obu izbach została Komunistyczna Partia Czechosłowacji (Komunistická strana Československa, KSČ), na którą głosowało 13\% wyborców. Trzecie miejsce zajęła koalicja Ruchu Chrześcijańsko-Demokratycznego, która w wyborach do Izby Ludu zdobyła poparcie 8,7\% wyborców Republiki Czeskiej i 19\% Słowaków. Czwarte miejsce zajęło Stowarzyszenie dla Moraw i Śląska (Společnost pro Moravu a Slezsko, SMS), uzyskując w Izbie Ludu poparcie 7,9\% wyborców. Z kolei w Izbie Narodów SMS uzyskało poparcie 9,1\%. Słowacka Partia Narodowa (Slovenska národná strana, SNS) zdobyła $11 \%$ poparcie w wyborach do Izby Ludu i 11,4\% w Izbie Narodów. Koalicja grupująca przedstawicieli mniejszości etnicznych uzyskała poparcie $8,6 \%$ głosów w wyborach do Izby Ludu i 8,5\% do Izby Narodów (Wiszniowski, 1998, s. 79-81).

W przypadku wyborów do Słowackiej Rady Narodowej (Slovenská národná rada, SNR) odbywały się one w oparciu o przepisy ustawy z dnia 16 marca 1990 r. (Zákon 1990/88). W Słowacji frekwencja w wyborach do Słowackiej Rady Narodowej wyniosła 95,39\%. W programach wyborczych wielu partii politycznych pojawiły się hasła integracji europejskiej, zerwania $\mathrm{z}$ systemem totalitarnym, gospodarki rynkowej, pluralizmu politycznego i własności środków produkcji oraz dopuszczenia kapitału zagranicznego. Partie słowackie domagały się równouprawnienia w ra- 
mach Federacji. Z kolei partie mniejszości narodowych i grup etnicznych postulowały konieczność zagwarantowania ich praw. Komunistyczna Partia Czechosłowacji akcentowała swój negatywny stosunek do niekontrolowanego bezrobocia, wyprzedaży majątku narodowego, prywatyzacji banków, rozpadu rolniczych spółdzielni produkcyjnych oraz komercjalizacji służby zdrowia (Szczepaniak, 1995, s. 47). Wybory te stanowiły pole rywalizacji pomiędzy ruchem obywatelskim Społeczeństwo Przeciwko Przemocy a konserwatywnym Ruchem Chrześcijańsko-Demokratycznym (Krest’anskodemokratické hnutie, KDH).

Tabela 1

Wyniki wyborów do Słowackiej Rady Narodowej w 1990 r.

\begin{tabular}{||l|c|c||}
\hline \multicolumn{1}{|c|}{ Ugrupowanie } & $\begin{array}{c}\text { Wynik } \\
(\mathbf{w} \%)\end{array}$ & $\begin{array}{c}\text { Liczba } \\
\text { mandatów }\end{array}$ \\
\hline Społeczeństwo Przeciwko Przemocy & 29,35 & 48 \\
\hline Ruch Chrześcijańsko-Demokratyczny & 19,21 & 31 \\
\hline Słowacka Partia Narodowa & 13,94 & 22 \\
\hline Komunistyczna Partia Słowacji* & 13,35 & 22 \\
\hline Węgierski Ruch Chrześcijańsko-Demokratyczny & 8,66 & 14 \\
\hline Partia Demokratyczna & 4,40 & 7 \\
\hline Partia Zielonych & 3,49 & 6 \\
\hline Inni & 7,60 & - \\
\hline Razem & 100,00 & 150 \\
\hline
\end{tabular}

* W wyborach 1990 r. Komunistyczna Partia Słowacji kandydowała pod szyldem Komunistycznej Partii Czechosłowacji.

Źródło: http://app.statistics.sk/webdata/_slov/volby90/php90.htm, 10.11.2016.

W latach 1990-1992 na ziemiach słowackich dała się zauważyć intensyfikacja organizowania uroczystości poświęconych pamięci osób związanych z Państwem Słowackim (1939-1945). Część z tych polityków jak np. Jozef Tiso, Alexander Mach, Vojtech Tuka czy Ferdinand Durčanský budziła spore kontrowersje. Z jednej strony byli oni architektami pierwszego państwa słowackiego, z drugiej jednak nie wolno zapominać o realiach, w jakich przyszło temu państwu funkcjonować, państwo to było satelitą III Rzeszy. Nacjonaliści i separatyści wykorzystywali każdą okazję związaną z uroczystościami do zademonstrowania swojej siły. Jak zauważa Andrzej J. Madera, ruch nacjonalistyczny i separatystyczny nie rozwijałby się tak prężnie, gdyby nie wsparcie finansowe silnego nacjonalistycznego słowackiego lobby w USA i Kanadzie (Madera, 1991, s. 37). Warto dodać, że w okresie Austro-Węgier ziemie słowackie należały do 
najsłabiej gospodarczo rozwiniętej części monarchii, a co za tym idzie miejscowa ludność była spauperyzowana. Dlatego też w drugiej połowie XIX i na początku XX w. znaczny odsetek emigrantów do obu Ameryk stanowili mieszkańcy Europy Środkowej (Żarna, 2015, s. 90).

Pojawiły się jednocześnie duże rozbieżności odnośnie wizji przyszłego państwa, w wyniku czego zaczął narastać kryzys we wzajemnych relacjach Czechów ze Słowakami. Miał on podłoże zarówno polityczne, jak i gospodarcze. Słowacy swoją odrębność akcentowali już w pierwszych dniach ,aksamitnej rewolucji”. Opozycjoniści ze Słowacji nie przyłączyli się do powstałego Forum Obywatelskiego, ale powołali własny ruch - Społeczeństwo Przeciwko Przemocy. Jednym z istotnych punktów programu VPN stało się stworzenie rzeczywistej federacji. Naciskały na to szczególnie Słowacka Partia Narodowa, Macierz Słowacka, przedstawiciele ugrupowań emigracyjnych w USA i Kanadzie oraz Ruch Chrześcijańsko-Demokratyczny (Szczepaniak, 1995, s. 53).

W chwili załamania monopolu Komunistycznej Partii Czechosłowacji (na ziemiach słowackich jej lokalnej przybudówki Komunistycznej Partii Słowacji, KSS) zaczęły powstawać liczne partie polityczne. Dominującą rolę odgrywało w tym okresie wspomniane Społeczeństwo Przeciwko Przemocy. Zwyciężyło w pierwszych demokratycznych wyborach parlamentarnych 1990 r., zdobywając 29,3\% głosów. Ruch VPN został założony w Bratysławie w dniu 20 listopada 1989 r., stając się główną opozycyjną siłą polityczną wobec ówczesnej władzy. Nie reprezentował on jednolitej formy ideowej, w jego skład wchodziły zarówno osoby związane z poprzednim reżimem, jak i działacze antykomunistyczni wywodzący się z kręgów inteligencji. Wśród tych osób można wymienić: Martina Bútorę, Jána Čarnogurskiego, Juraja Flamika, Gabrielę Kaliską, Vladimíra Kompánka, Jána Langoša, Františka Mikloškę, Olega Pastiera, Rudolfa Sikorę, Martina M. Šimečkę, Petera Tatára, Petera Zajaca, Miloša Žiaka (Żarna, 2015, s. 91).

W dniu 25 listopada 1989 r. przedstawiciele ruchu ogłosili swój program polityczny, który był oparty na zasadach liberalnej demokracji. Żądali przeprowadzenia wolnych wyborów i usunięcia z ustawy zasadniczej przepisów o przewodniej roli partii komunistycznej. Akcentowali konieczność budowy społeczeństwa obywatelskiego, państwa prawa i wejścia do struktur europejskich. Na przełomie lat 1989 i 1990 zauważalna była jednak tendencja słabnięcia poparcia dla VPN. Jego przedstawicieli oskarżano o brak umiejętności podejmowania kluczowych decyzji, istotny wpływ na taki stan rzeczy miało też pogorszenie warunków życia. Tak 
duża różnorodność ideowa VPN powodowała sytuację, w której zaczęły wyodrębniać się poszczególne nurty ideologiczne, z których najsilniejsza stała się frakcja chrześcijańsko-demokratyczna (Zenderowski, 2007, s. 300-301).

Ostatecznie przywódca wspomnianej frakcji Ján Čarnogurský opuścił Społeczeństwo Przeciwko Przemocy, tworząc 17 lutego 1990 r. w Nitrze własne ugrupowanie: Ruch Chrześcijańsko-Demokratyczny. Na początku lat 90. XX w. była to partia skupiająca w swoich szeregach polityków wielu nurtów światopoglądowych. W wyniku secesji, w KDH powstał Słowacki Ruch Chrześcijańsko-Demokratyczny (Slovenské krest’anskodemokretické hnutie, SKDH), który odgrywał marginalną rolę. W późniejszym okresie ugrupowanie to zmieniło nazwę na Unię Chrześcijańsko-Społeczną, aby w 1998 r. połączyć się ze Słowacką Partią Narodową. Sam J. Čarnogurský opowiadał się za utrzymaniem federacji, chociaż zdawał sobie sprawę, że dojdzie w końcu do jej zaniku. Miało to swój wyraz w głosowaniu nad deklaracją o suwerenności Słowacji i przyjęciu ustawy zasadniczej - w obu tych przypadkach KDH wypowiadała się przeciwko. Do czołowych polityków KDH zaliczani byli: Tibor Böhm, Ivan Čarnogurský, Ivan Hoffman, Anton Hykisch, Ján Klepáč, Štefan Kružliak, Viliam Oberhauser, Hana Ponická, Anton Selecký, Miroslav Tahy, Konstantin Viktorín. Partia ta uzyskała w wyborach parlamentarnych poparcie 19,2\% (Zenderowski, 2007, s. 304-305).

Słowacka Partia Narodowa, uzyskała poparcie 13,9\% wyborców. Ugrupowanie to powstało w 1990 r., miało charakter nacjonalistyczny i radykalny. Część jej działaczy nawiązywała do partii o tej samej nazwie, powstałej jeszcze w ramach Austro-Węgier, która w okresie dwudziestolecia międzywojennego domagała się dla Słowaków autonomii. W swojej retoryce członkowie tej partii wielokrotnie odwoływali się do tradycji Państwa Słowackiego. Przedstawiciele SNS jako pierwsi wysunęli program suwerenności Słowacji. Do czołowych działaczy należeli: Marián Andel, Ludovít Černak, Anton Hrnko, Anna Maliková-Belousovova, Vit’azoslav Moric, Stanislav Pánis, Jozef Prokeš, Ján Slota. Radosław Zenderowski zwraca uwagę na fakt, że nacjonalizm stał się znakiem rozpoznawczym tej partii, która w swojej ideologii prawie wyłącznie odnosiła się do pisarzy emigracyjnych jak Milan S. Durica, Jozef Kirchbaum, Štefan Polakovič czy František Vnuk (Zenderowski, 2007, s. 302).

Komunistyczna Partia Słowacji (Komunistická strana Slovenska, KSS) w wyborach 1990 r. uzyskała poparcie 13,3\%. Po ,aksamitnej rewolucji” jej członkowie musieli odnaleźć się w nowych realiach poli- 
tycznych. Część polityków stała na stanowisku, że ugrupowanie to powinno mieć charakter socjaldemokratyczny, w konsekwencji zmienili nazwę na Partię Lewicy Demokratycznej (Strana demokratickej l'avice, SDL). W rzeczywistości nazwa SDL' zaczęła obowiązywać od 1991 r., przez blisko rok funkcjonowała nazwa KSS-SDL. Politycy tej partii, odrzucając pierwszą część nazwy, deklarowali chęć całkowitego zerwania z komunistyczną przeszłością. Czołowym działaczem był Peter Weiss. Z kolei politycy, którzy nie akceptowali idei partii o charakterze socjaldemokratycznym, w styczniu $1991 \mathrm{r}$. zdecydowali się na założenie Związku Komunistów Słowacji (Zväz komunistov Slovenska, ZKS). Dodatkowo w lutym 1991 r. powstała Komunistyczna Partia Słowacji '91 (Komunistická strana Slovenska `91, KSS 91). Oba ugrupowania powołały w dniu 29 sierpnia 1992 r. Komunistyczną Partię Słowacji, która pod względem formalnym nie była spadkobiercą dawnej KSS. Do czołowych działaczy należeli Vladimír Ďad’o i Jozef Ševc (Kopeček, 2003, s. 163).

Do parlamentu dostała się jeszcze koalicja dwóch partii węgierskich: Wspólnoty (Együttélés) i Węgierskiego Ruchu Chrześcijańsko-Demokratycznego (Mad'arské krest’anskodemokratické hnutie, MKHD), która uzyskała 8,7\% poparcia. Wspólnota powstała pod koniec marca $1990 \mathrm{r}$. z inicjatywy Miklósa Duraya, byłego dysydenta i sygnatariusza Karty 77, któremu początkowo udało się namówić do współpracy przedstawicieli Rusinów, Ukraińców, Polaków ze Śląska Cieszyńskiego i Niemców. Z czasem działalność partii ograniczała się do obrony praw mniejszości węgierskiej. M. Duray krytykował niektóre ugrupowania węgierskie za uległość wobec VPN i brak nieustępliwości w kwestii praw mniejszości węgierskiej. Politycy tej partii często posługiwali się retoryką nacjonalistyczną. Jednoznacznie też popierali członkostwo we Wspólnotach Europejskich. Wśród czołowych polityków można wymienić: Árpáda DukęZólyomiego. Radosław Zenderowski zwrócił uwagę na pewien paradoks: partię tę założył były dysydent, a jej członkami w dużym stopniu byli działacze komunistyczni (Zenderowski, 2007, s. 306).

W dniu 17 marca 1990 r. w Bratysławie został założony Węgierski Ruch Chrześcijańsko-Demokratyczny i miał podobne korzenie jak KDH. Wspólnym mianownikiem obu ugrupowań był katolicyzm, różniły się one jednak zasadniczo w kwestiach narodowych. Do czołowych działaczy należeli: Béla Bugár, Pál Csáky oraz Kálmán Janics (Kopeček, 2003, s. 158).

Trzecią węgierską partią, która w analizowanym okresie odgrywała znaczącą rolę była Węgierska Niezależna Inicjatywa (Mad'arská nezávislá iniciatíva, MNI). Została założona 18 listopada 1989 r. jako stowa- 
rzyszenie, oficjalnie jako partia funkcjonowała od 19 lutego 1990 r. Była ugrupowaniem liberalnym, proeuropejskim, członkami byli przeważnie inteligenci, byli dysydenci. Jej politycy stali na stanowisku współpracy $\mathrm{z}$ partiami słowackimi ponad narodowymi podziałami, co spotkało się z krytyką ze strony węgierskich ugrupowań nacjonalistycznych. W 1992 r. MNI zmieniła nazwę na Węgierską Partię Obywatelską (Mad’arská občianska strana, MOS). Czołowymi działaczami byli: Lajos Grendel, László Nagy, Alexander Varga oraz Gábor Zászlós (Kopeček, 2003, s. 159).

Niewielkie poparcie uzyskała Partia Demokratyczna (Demokratická strana, DS): 4,4\%. Ugrupowanie to nawiązywało do tradycji sprzed 1948 r., a przede wszystkim doświadczeń Słowackiego Powstania Narodowego. Po ,aksamitnej rewolucji” powrócono do historycznej nazwy. W swoim programie z 1990 r. jego autorzy akcentowali, że DS jest partią narodową, demokratyczną, liberalną. Podkreślano jej antykomunizm. Występowała przeciwko rozpadowi Federacji, a z czasem stawała się coraz bardziej prawicowa. Czołowymi działaczami byli Božena Badálova, Ivan Brndiar, Peter Brňak, Jozef Dubniček, Michal Géci, Ján Holčík, Ol'ga Keltošova, Martin Kvetko, Ján Majer, Peter Mattoš, Stanislav Novák oraz Hana Zelinová (Zenderowski, 2007, s. 303-304).

W wyborach 1990 r. w koalicji z Partią Demokratyczną wystąpiła Partia Zielonych na Słowacji (Strana zelených na Slovensku, SZS), która zdobyła poparcie na poziomie 3,5\%. Zarejestrowano ją na początku 13 lutego 1990 r. jako Partia Zielonych na Słowacji. Kilka dni wcześniej powstała w Czechach. Obie partie postanowiły występować pod wspólnym szyldem jako Partia Zielonych (Strana zelených, SZ). Opowiadały się one przeciwko rozpadowi Federacji. Partię reprezentowali Gabriela Kaliská, Juraj Mesík, Jozef Pokorný oraz Peter Sabo. SZS popierała akcesję Słowacji do struktur euroatlantyckich. Przedstawiciele tej partii wchodzili często w konflikt z rządzącymi, jak np. protestując przeciwko budowie kompleksu hydroenergetycznego Gabczikovo-Nagymaros. Utrzymywała ścisłe związki z partią Zielonych w Niemczech. Podobnie jak w przypadku innych ugrupowań, procesy dezintegracyjne nie ominęły też i SZS. Do dużego rozdźwięku wśród członków partii doszło w związku ze stosunkiem do ustawy językowej. Po 1992 r. odgrywała ona już marginalną rolę (Zenderowski, 2007, s. 305).

Po wyborach w 1990 r. koalicję rządową zawiązały Społeczeństwo Przeciwko Przemocy, Ruch Chrześcijańsko-Demokratyczny i Partia Demokratyczna. Członkiem koalicji została również liberalna Węgierska 
Niezależna Inicjatywa. Na czele rządu stanął Vladimír Mečiar z VPN, dotychczasowy minister spraw wewnętrznych (Madera, 1991, s. 37-38).

Nowo wybrany parlament miał m.in. za zadanie opracować konstytucję federalną. Z inicjatywy V. Mečiara, w dniach 8-9 sierpnia 1990 r. doszło w Trenczianskich Teplicach do spotkania przedstawicieli trzech rządów: federalnego, czeskiego i słowackiego oraz Forum Obywatelskiego i Społeczeństwa Przeciwko Przemocy. Zdecydowano, aby pozostawić w kompetencji władz federalnych politykę obronną, zagraniczną, celną i podatkową, sprawy socjalne oraz tworzenie norm prawnych. Powołano dziesięć komisji, które miały za zadanie ustalić szczegółowe kompetencje pomiędzy władzami obu republik a władzami federalnymi (Jagodziński, 1990, s. 6).

Słowacka Rada Narodowa w dniu 25 października 1990 r. uchwaliła ustawę o słowackim języku jako urzędowym, obowiązującym na równi z czeskim (Zákon 1990/428). Na terenie Słowacji nazwy miejscowe miały mieć brzmienie słowackie. Ustawa ta uderzyła przede wszystkim w przedstawicieli mniejszości węgierskiej, wywołując jednocześnie niezadowolenie skrajnych nacjonalistów słowackich $\mathrm{z}$ faktu równouprawnienia języka słowackiego z czeskim. Demonstrowali oni przed budynkiem Słowackiej Rady Narodowej, wznosząc hasła antyczechosłowackie, obiektem ataku stał się też sam Václav Havel (Madera, 1991, s. 38).

W drugiej połowie 1990 r. hasła emancypacji zostały włączone do programów większości partii politycznych. Nie uwzględniały one jednak perspektywy rozpadu Federacji. Deklaracji suwerenności domagała się jedynie Słowacka Partia Narodowa i drobne ugrupowania nacjonalistyczne. Czynnikiem, który wydatnie przyczynił się do procesu separacji było utworzenie przez Słowacką Radę Narodową funkcji ministra ds. stosunków międzynarodowych w rządzie słowackim i powierzenie jej Milanowi Kňažce. Rozpoczął się proces formowania podstaw słowackiej dyplomacji (Mojžita, 2004, s. 15-17).

Prace nad podziałem kompetencji delegacje rządowe ukończyły w dniu 13 listopada 1990 r. W rezultacie do 20 listopada podział zatwierdziły wszystkie trzy rządy i trafił on ostatecznie na forum obu parlamentów republikańskich. Parlament słowacki zatwierdził te zmiany, z kolei czeski uczynił to z poprawkami. Słowacy zagrozili, że jeżeli Zgromadzenie nie uchwali projektu w jego pierwotnej wersji, uzna priorytet własnych ustaw nad federacyjnymi. Ostatecznie dnia 12 grudnia Zgromadzenie uchwaliło tzw. ustawę kompetencyjną (Ústavný) ograniczającą kompetencje władz federalnych do obronności państwa, polityki zagranicznej, przemysłu paliwowo-energetycznego i wydobywczego oraz systemu walutowego, 
oraz podatkowego. Ustawa ta miała znaczenie doraźne - pozwoliła na uchwalenie budżetu na rok 1991 oraz wstrzymała, przynajmniej na jakiś okres czasu, proces rozpadu Federacji (Szczepaniak, 1995, s. 55).

W dniu 10 lutego 1991 r. w centrum Bratysławy zebrała się ośmiotysięczna manifestacja popierająca ideę niepodległości Słowacji. W wystąpieniach wielokrotnie nawiązywano do utworzonego w 1939 r. Państwa Słowackiego i domagano się rehabilitacji jego twórcy i pierwszego prezydenta Jozefa Tisy. Wśród przemawiających był m.in. Pavol Čarnogurský. Rzecznik prezydenta Vaclava Havla, Michael Žantovský, oświadczył, że gwałtowny wzrost temperatury politycznej na Słowacji jest wynikiem wspólnych działań komunistów oraz ludzi traktujących Państwo Słowackie jako złoty okres w dziejach narodu. Oskarżył również premiera Vladimíra Mečiara o sabotowanie reformy gospodarczej (Neosocjalizm, s. 7).

Narada czołowych polityków obu republik, zwołana z inicjatywy Václava Havla w lutym 1991 r., nie przyniosła rozstrzygnięć. Podjętą ideę konfederacji lansowaną przez polityków słowackich odrzucili Czesi, przeciwstawiając jej koncepcję mocnej i sprawnej struktury państwowej, umożliwiającej przeprowadzenie transformacji państwa. Ostatecznie w dniu 17 czerwca 1991 r. ustalono, że parlamenty obu republik zawrą umowę wewnątrzpaństwową określającą zasady ustroju federacji, którą będzie respektować Zgromadzenie Federalne, uchwalając nową konstytucję (Morawiec, 1991, s. 41-42).

Wkrótce po wyborach parlamentarnych doszło do konfliktu pomiędzy skrzydłem promecziarowskim a pozostałymi członkami Społeczeństwa Przeciwko Przemocy pod przywództwem Fedora Gala, w konsekwencji czego w kwietniu 1991 r. Vladimír Mečiar został odwołany z funkcji szefa rządu (Jednaka, 1998, s. 113; Barański, Czyż, 2005, s. 360). Grupa jego zwolenników założyła dnia 3 maja 1991 r. Ruch na rzecz Demokratycznej Słowacji, który znalazł się w opozycji. Ugrupowanie to od początku kreowało się na adwokata słowackich interesów narodowych. V. Mečiara zaczęto oskarżać o wykorzystywanie resortów siłowych do realizacji własnych interesów. Ostatecznie na stanowisku premiera zastąpił go przewodniczący Ruchu Chrześcijańsko-Demokratycznego Ján Čarnogurský (Cichosz, 2010, s. 136-137).

W dniu 16 września 1991 r. premier rządu słowackiego Ján Čarnogurský i przewodniczący Słowackiej Rady Narodowej František Mikloško wystosowali list otwarty do prezydenta Václava Havla, w którym ostro zaprotestowali przeciwko sformułowaniu, które zostało zawarte w projekcie traktatu czechosłowacko-niemieckiego o nieprzerwalnym istnieniu 
Czechosłowacji od $1918 \mathrm{r}$. Ich zdaniem, tworząc projekt traktatu powinno się wziąć pod uwagę istnienie w latach 1939-1945 Państwa Słowackiego, które było uznane oficjalnie przez wiele państw. Na początku września 1991 r. grupa polityków z V. Mečiarem opublikowała dokument Inicjatywa na rzecz demokratycznej Słowacji wzywający parlament słowacki do ogłoszenia suwerenności republiki i uchwalenia konstytucji. Jak już wspomniano, aby podkreślić swoją tożsamość, skrajnie radykalni politycy słowaccy wykorzystywali każdą okazję do demonstracji. Istotnym punktem odniesienia była gloryfikacja osób pełniących ważne funkcje państwowe w okresie funkcjonowania Państwa Słowackiego. W dniu 13 października w Bytczy odbyły się uroczystości 104. rocznicy urodzin ks. Jozefa Tiso, prezydenta Słowacji w latach 1939-1945, skazanego za kolaborację z Niemcami na karę śmierci (Szczepaniak, 1995, s. 56). Dnia 14 marca 1991 r., w rocznicę utworzenia Państwa Słowackiego, Macierz Słowacka zorganizowała w Bratysławie demonstrację domagającą się niezależnej Słowacji. Obecny na wiecu V. Havel spotkał się z wrogością zebranych, nie dopuszczono go nawet do mikrofonu (Jagodziński, 1991, s. 6). Wśród części słowackiej opinii publicznej ukształtował się stereotyp, że Czesi zawsze wykorzystywali Słowaków i nie życzą sobie ich równoprawnej pozycji we wspólnym państwie (Polačková, 1997, s. 146).

Separatyzm słowacki rozbudził w Czechach tendencje antysłowackie. Ideę samodzielnego państwa czeskiego podjął zwłaszcza prawicowy Sojusz Obywatelsko-Demokratyczny (Občanská demokratická aliance, ODA). Orędownikiem zachowania federacji pozostawał prezydent. O jej przyszłości, zdaniem V. Havla, powinni zadecydować nie politycy, lecz narody. W lipcu 1991 r. Zgromadzenie Federalne uchwaliło ustawę, dzięki której zostało umożliwione przeprowadzenie referendum, a 5 listopada zdecydowano o trybie jego przeprowadzenia. Miało ono odbyć się w grudniu. Zgromadzenie Federalne odrzuciło jednak projekty pytań zawartych w referendum (Szczepaniak, 1995, s. 56).

W dniu 17 listopada 1991 r. Václav Havel w przemówieniu telewizyjnym dramatycznie zaapelował do społeczeństwa o pomoc w ratowaniu państwa. Zapowiedział, że wniesie do parlamentu projekty ustaw, które wzmocnią pozycję prezydenta, dając możliwość rozpisania referendum bez konieczności stanowiska parlamentu w tej sprawie. Zapowiedział również przedstawienie projektów kilku ustaw: o Federacji Czechosłowackiej, o warunkach rozwiązania parlamentu i przedterminowych wyborach, o nowej strukturze zgromadzenia Federalnego oraz projekt nowej ordynacji wyborczej (Madera, 1991, s. 36). 
Słowaccy i czescy studenci zaproponowali w dniu 22 listopada 1991 r., aby obywatele w specyficzny sposób wypowiedzieli się czy chcą żyć we wspólnym państwie. Miało się to odbyć dnia 24 listopada poprzez zapalenie po głównym wydaniu dziennika telewizyjnego dwóch dodatkowych stuwatowych żarówek. Pozytywnej odpowiedzi udzieliło 2750000 gospodarstw domowych, czyli około 5 milionów obywateli, połowa uprawnionych do głosowania (Żarna, 2011, s. 478).

Spór o formę państwa rozgorzał wiosną 1992 r. podczas kampanii wyborczej do parlamentów federacji oraz obu republik. Politycy Obywatelskiej Partii Demokratycznej (Občanská demokratická strana, ODS) Václava Klausa zakładali w swoim programie odejście od wcześniejszych ustaleń decentralizacyjnych i budowę „funkcjonalnej federacji”. Z kolei HZDS V. Mečiara proklamował hasło konfederacji, a więc dalszego rozluźnienia struktury państwa. Jak najszybszego rozdzielenia państwa domagały się ugrupowania nacjonalistyczne i SNS. W rezultacie wyborów z 1992 r. w skład koalicji rządzących obu republik weszły partie domagające się już otwarcie rozpadu federacji. W parlamencie czeskim był to ODS w słowackim HZDS (Szczepaniak, 1995, s. 57).

Po aksamitnej rewolucji w Czechach i na Słowacji w 1990 r. odbyły się wybory do Zgromadzenia Federalnego. Zwyciężyły w nich dwa ruchy polityczne: Forum Obywatelskie i Społeczeństwo Przeciwko Przemocy. W przypadku wyborów do Słowackiej Rady Narodowej większość partii politycznych akcentowała chęć akcesji do struktur europejskich oraz równouprawnienia $\mathrm{w}$ ramach federacji. $\mathrm{Z}$ czasem narastały rozbieżności pomiędzy Czechami a Słowakami odnośnie wizji przyszłego państwa. Spośród polityków czeskich i słowackich odrębność akcentowali Vacláv Klaus i Vladimír Mečiar oraz przedstawiciele partii nacjonalistycznych. $\mathrm{Z}$ kolei największym orędownikiem utrzymania federacji był prezydent Vacláv Havel. W związku z narastającymi tendencjami nacjonalistycznymi wśród Czechów i Słowaków proces dezintegracji wspólnego państwa był nie do powstrzymania. Ostatecznie 1 stycznia 1993 r. na politycznej mapie Europy pojawiły się dwa nowe państwa: Republika Czeska i Republika Słowacka.

\section{Bibliografia}

Barański M., Czyż A. (2005), Słowacja, w: Systemy polityczne państw Europy Środkowej i Wschodniej, red. M. Barański, E. Piaskownik, Katowice. 
Cichosz M. (2010), Gabinety na Słowacji po 1990 roku, w: Współczesna Słowacja. Sytuacja wewnętrzna i pozycja międzynarodowa, red. E. Pałka, Wydawnictwo Arboretum, Wrocław.

Jagodziński A. (1990), Jednak Federacja, „Gazeta Wyborcza” z 22 VIII.

Jagodziński A. (1991), Prawie lincz, „Gazeta Wyborcza” z 15 III.

Jednaka W. (1998), Partie polityczne wybranych państw Europy ŚrodkowoWschodniej, w: Demokracje Europy Środkowo-Wschodniej w perspektywie porównawczej, red. A. Antoszewski, R. Herbut, Wydawnictwo Uniwersytetu Wrocławskiego, Wrocław.

Kopeček L. (2003), Stranický systém Slovenska, w: P. Fiala, R. Herbut i in., Střeoeuropské systémy politických stran. Česká republika, Mad'arsko, Polsko a Slovensko, Masarykova Univerzita v Brně, Brno.

Madera A. J. (1991), Na drodze do niepodległości. Stowacki system polityczny w okresie transformacji, Firma „SAS” Wanda Tarnawska, Rzeszów.

Mojžita M. (2004), Kňažko/Demeš/Kňažko. Formovanie slovenskej dyplomacie v rokoch 1990 až 1993, Slovenská akadémia vied, Bratislava.

Morawiec R. (1991), Czecho-Stowacja, „Europa Środkowo-Wschodnia”, R. I.

Neosocjalizm? (1991), „A do Z” z 12 II.

Orlof E. (2003), Transformacja polityczna w Stowacji w ostatniej dekadzie XX wieku, w: I. Stawowy-Kawka, W. Rojek, Państwa europejskie na drodze do niepodległości (w drugiej połowie XIX i XX wieku). Studia oferowane Profesorowi Marianowi Zgórniakowi, Towarzystwo Wydawnicze Historica Jagiellonica, Kraków.

Polačková Z. (1997), Przejawy nacjonalizmu i problemy mniejszości na Słowacji po 1989 r., w: Fenomen nowoczesnego nacjonalizmu w Europie Środkowej, red. B. Linek, J. Lüer, K. Struve, Państwowy Instytut Naukowy - Instytut Śląski, Opole.

Rychlík J. (1999), Rozděleni Československa 1989-1992, „Prace Komisji Środkowoeuropejskiej PAU", t. XVII.

Suk J. (1997), Občanské fórum. Listopad-prosinec 1989, t. 1: Události, Doplněk Brno - Ústav pro soudobé dějiny, Praha.

Szczepaniak M. (1995), Czechosłowacja w latach 1989-1992. Od ,aksamitnej rewolucji” do ,aksamitnego” rozpadu federacji, „Prace Politologiczne”, z. 226.

Schuster R. (1999) [wywiad], Bez czerwonej kartki, „Polityka” z 11 XII.

Ústavný zákon z 20. aprila 1990 o zmene názvu Česko-slovenskej federativnej republiky, Z.z. 1990, č. 101.

Wiszniowski R. (1998), Wybory parlamentarne $w$ krajach Europy ŚrodkowoWschodniej. Polityczne konsekwencje systemów wyborczych, w: Demokracje Europy Środkowo-Wschodniej w perspektywie porównawczej, red. A. Antoszewski, R. Herbut, Wydawnictwo Uniwersytetu Wrocławskiego, Wrocław.

Ústavný zakon z 12. Decembra 1990 ktorým sa mení ústavný zákon č. 143/1968 Zb. o československej federácii, Z.z. 1990, č. 556. 
Zákon Slovenskej národnej rady z 16. marca 1990 o vol’bách do Slovenskej národnej rady. Z.z. 1990, č. 80.

Zákon Slovenskej národnej rady z 25. Octobra 1990 o úradnom jazyku v Slovenskej republikę, Z.z. 1990, č. 428.

Zenderowski R. (2007), Nad Tatrami blyska się... Stowacka tożsamość narodowa $w$ dyskursie politycznym w Republice Stowackiej (1989-2004), Wydawnictwo Uniwersytetu Kardynała Stefana Wyszyńskiego, Warszawa.

Żarna K. (2015), Od Mečiara do Dzurindy. Główne kierunki polityki zagranicznej Republiki Słowackiej w latach 1993-2002, Wydawnictwo Uniwersytetu Rzeszowskiego, Rzeszów.

Żarna K. (2011), Po rozwodzie. Republika Czeska w polityce zagranicznej Republiki Słowackiej (1993-2002), w: Polska - Słowacja - Europa Srodkowa w XX wie$k u$, red. J. Pisuliński, E. Rączy, K. Żarna, Wydawnictwo Uniwersytetu Rzeszowskiego, Rzeszów.

\section{Before the divorce. Political situation in Slovakia within the Czech and Slovak Federal Republic (1990-1992)}

\section{Summary}

After "the Velvet Revolution" in Slovakia and Czechia in 1990, the election to the Federal Assembly took place. Two political movements won this election: Civic Forum and Public Against Violence. In the elections to the Slovak National Council a majority of political parties emphasized the need to join European structures as well as ensure equal rights within the Czech-Slovak federation. After a while, differences between Slovakia and Czechia in their respective visions of the future state emerged. Among Czech and Slovak politicians, Vacláv Klaus, Vladimír Mečiar and the representatives of Nationalist Parties stressed separatist trends, whereas President Vacláv Havel was the main supporter of maintaining the federation. In connection with the growing nationalist sentiments among Czechs and Slovaks, the disintegration process of the state could not be stopped. Finally, on January 1, 1992, two new states appeared on the political map of Europe: the Czech Republic and Slovak Republic.

Key words: The Czech and Slovak Federal Republic, Vacláv Klaus, Vladimír Mečiar, Vacláv Havel, disintegration 